International Journal of Small Business and Entrepreneurship Research

Vol.8, No.2, pp.17-31, April 2020

Published by ECRTD-UK

Print ISSN: 2053-5821(Print), Online ISSN: 2053-583X (Online)

\title{
Optimalization Model of University Business Incubator Role in New Entrepreneur and MSMEs Development in Indonesia
}

\author{
Nila Tristiarini , Melati Oktafiyani, Agung Sedayu \\ University of Dian Nuswantoro \\ Email : nila.tristiarini@dsn.dinus.ac.id
}

\begin{abstract}
Business incubators have an important role in the local economy as an outcome of the value creation coming from maintaining and developing micro, small, and medium enterprises (MSMEs) which are innovative and growing rapidly. The purpose of this research is to build a model that can be used for the business incubator management process in the universities, thereby getting the optimal role in developing new entrepreneurs and MSMEs, especially in Indonesia. This model is also expected to be used to develop business incubators internationally. The originality of this research lies in the creation of a business incubator role model. The research method uses a literature review of the outcomes of previous studies and of obtaining business incubator information managed by 69 universities in Indonesia. The research is generating a model composed of several stages in order to optimize the role of a university business incubator in dividing the incubation stage into three stages/phases: Pre-Incubation, Incubation, and PostIncubation.
\end{abstract}

KEYWORDS: business incubator, MSMEs development, new entrepreneur, university business incubator

\section{INTRODUCTION}

Indonesia is a country having a very rapid population growth rate. Indonesia has currently a population of 269 million people or $3.49 \%$ of the total world population. Indonesia ranks as the fourth most populous country in the world after China with 1.42 billion people, India in 1.37 billion people, and the United States with 328 million people (Worldometers, 2019). A very high population has an impact on very high employment needs for residents of productive age. The high employment needs and rising unemployment have made various parties work together to overcome. One of the overcoming efforts is by creating new businesses that are able to absorb labor. Efforts to develop new businesses must of course also be supported by parties, agencies or institutions, one of which is through business incubators. Indonesia itself, the incubator has become a hope for many parties to become an alternative solution for employment in Indonesia. One way the government has taken to grow and develop small businesses is through a business incubator program. Business incubators are considered important for the local economy as a result of perceived value creation originating from maintaining and developing innovative and rapidly growing micro, small and medium enterprises (MSMEs). Research on business incubators shows that business incubators are a significant tool for sustainable 
International Journal of Small Business and Entrepreneurship Research

Vol.8, No.2, pp.17-31, April 2020

Published by ECRTD-UK

Print ISSN: 2053-5821(Print), Online ISSN: 2053-583X (Online)

economic development (Babwah and David, 2014). Business incubators are mapped into Corporate Private Incubators (CPIs), Business Innovation Centers (BICs), Independent Private Incubators (IPIs) and University Business Incubators (UBIs) (Grimald, 2005).

The Indonesian Business Incubator Association (AIBI) states that in the year of 2019, the business incubator reached 150 institutions, although the number is relatively small, but this number has greatly increased compared to previous years. Likewise, in terms of quality, business incubators are now able to create new entrepreneurs in various fields. Business incubators can also be a means of strengthening the capacity to create new entrepreneurs. The main role of the business incubator is to assist MSMEs, strengthen MSES's ability comprehensively following the incubation process. Participation in developing business incubators is not only the responsibility of the government, but all parties, including universities, must participate in building business incubators as a form of responsibility to the community. Indonesia itself, the history of business incubators has been pioneered since 1993 which was formed by universities in Indonesia. The majority of business incubators accommodate students who are interested and have potential business ideas. In the 2019 year, there were 48 state universities and 32 private universities had business incubation institutions. Even though Indonesia has 4,600 tertiary institutions, the number of tertiary institutions with business incubators is only $1.47 \%$ of the total number of universities in Indonesia. At present, the government is intensively implementing mentoring programs for MSMEs, wherein the mentoring program the government involves universities which concern about entrepreneurship to be able to assist MSMEs more optimally increase the business (http://aibinetwork.com/).

The development of the number of business incubators is not comparable to the development of the number of new businesses and MSMEs in Indonesia. The Ministry of Cooperatives and SMEs Republic of Indonesia report that in terms of units, MSMEs have a share of around $99.99 \%$ (62.9 million units) of the total number of business operators in Indonesia in 2018, while large businesses are only $0.01 \%$ or around 5400 units. The contribution of the micro, small and medium enterprise sector to gross domestic product increased from 57.84 percent to 60.34 percent in the last five years. Employment absorption in this sector also increased, from 96.99 percent to 97.22 percent in the same period. The development of MSMEs is increasingly being carried out by the government and other parties to improve the performance of MSMEs. One of the efforts to achieve the development of MSME is through the development of MSME which refers to the ASEAN Policy Blueprint for SME Development (APBSD). In APBSD, the development of MSMEs is carried out through five programs, namely the entrepreneurship development program, improvement of marketing capabilities, access to finance, access to technology and conducive policies. All programs can surely be achieved by having parties who continuously assist MSMEs through business incubators.

Dey (2012) suggested that the development of MSME is very important for the economic development of a country. Many research has found evidence supporting the argument that small enterprises, especially small businesses with high growth, creating jobs and 
International Journal of Small Business and Entrepreneurship Research

Vol.8, No.2, pp.17-31, April 2020

Published by ECRTD-UK

Print ISSN: 2053-5821(Print), Online ISSN: 2053-583X (Online)

increasing welfare (Stokes \& Wilson 2010). But researchers also show that despite the small enterprises' positive impact on the economy, these small and new enterprises are likely feeble and vulnerable especially during their first years. Most of the small and new enterprises failed as soon as they started and only a small portion of their businesses succeeded in growing (Stokes \& Wilson, 2010). Incubation programs can provide support to reduce this failure. Business incubators have the potential to strengthen local and national economies, commercialize new technologies and import substitutions. The main challenges for the establishment and survival of the company are the management of the organization, distribution channels, technology, markets, infrastructure, finance, and sources of raw materials. Incubators provide support to MSMEs, equipping MSMEs with the necessary skills, resources, and environment that are conducive to running their business, especially during the initial business phase. Business incubation is a very important program for MSMEs since helps reduce risk, failure rates and maintain the sustainability, and increase growth during the initial stages of business.

Previous studies have shown that business incubators have a very important role in the development of new businesses. Dee, et al. (2011); Monsson \& Jorgensen (2016) provides empirical evidence on the role and effectiveness of business incubation that is capable of supporting the development of new company be able to grow and develop rapidly after going through the process of mentoring and incubation. Aggarwall, et al. (2012), analyzed that the incubation of technology and business has the potential to promote technological innovation and entrepreneurship, it is also supported by research conducted by Shepard (2013). The research by Shepard (2013) provides an empirical analysis of business technology incubation and concluded that all business incubation provides more benefits and helps in reducing poverty. The business incubator has three parts, the first part represents the type of incubator, the core of the incubator and its purpose, the second part represents the role of the business incubator in pushing the dimensions of local entrepreneurship and the third part describes the building of business incubators and helps them to start entrepreneurship (Lesakova et al., 2012 and Meru, et al., 2011). The importance of the role of the business incubator in the development of MSMEs is not always followed by the condition that MSMEs are able and willing to follow the entire process of business incubation itself, many MSMEs which do not carry out the incubation process until the process is completed, which ultimately impacts on the failure of the incubation program and the failure of the MSME business to grow and develop (Beats, 2013). The role of business incubator will be a maximum also depends on the human resources involved in it, according to Xu (2010), Petrucci (2018), Redondo \& Camarero (2017) and Cantu (2015) states that the reach pre-incubated better, the incubator manager must be competent, qualified, and highly skilled. The greater the manager's experience in the world of business and entrepreneurship, the greater the ability to assist business and networking activities in an incubator. Managers who do not have an entrepreneurial profile will weaken incubation access to other business networks and prove inefficient in business training. Thus, need an optimization strategy for business incubators so that the programs arranged have a significant impact on solving problems and developing new businesses or MSMEs coming in into the incubation program. 
International Journal of Small Business and Entrepreneurship Research

Vol.8, No.2, pp.17-31, April 2020

Published by ECRTD-UK

Print ISSN: 2053-5821(Print), Online ISSN: 2053-583X (Online)

The research filed a problem formulation is how to make a model optimizing the role of business incubator managed by the universities is able to develop SMEs could run businesses independently and sustainably by training and assistance program. The purpose of this study is to build a model that can be used for the management of university business incubators, thereby the role is optimal in developing new entrepreneurs and MSMEs, especially in Indonesia. This model is expected to be used to develop business incubators internationally. The originality of this research lies in the creation of a business incubator role model owned by universities which is certainly different from business incubators managed by government institutions or others since universities have adequate intellectual capital and other resources, universities are nonprofit organizations and is a source of research results and technological development that can be used to develop MSMEs. This research builds a model that can be used to optimize the role of business incubators in developing MSMEs hence can grow and develop, in which MSMEs have a very important role in economic growth in Indonesia and one of the means to increase employment thereby reducing unemployment and poverty in Indonesia.

\section{LITERATURE REVIEW}

Mubaraki and Musler (2013) define business incubators as economic and social development entities that are designed to advise potential startup companies, help them build, and accelerate their growth and success through comprehensive business assistance programs. The ultimate goal is to produce a successful business that will make this program financially viable and independent. The purpose of establishing a business incubator is to develop new businesses that are fostered by a profit-oriented company, have a good an appropriate management in organizational and financial, and become a sustainable company, so that it will ultimately have a positive impact on society at large (Lesakova, 2012). The incubator program helps fill the gap by providing imperfect training to entrepreneurs, space to launch a business, and in some cases finding between new business owners and others who are located to invest in the business concerned and develop it in the future.

Business incubators are divided into several types. Depending on lies in the way of service, in the organizational structure, and the type of clients on serve. Classic incubators are business incubators that are oriented towards providing support in starting a business through advice, space to rent, and offering administrative infrastructure and other services. Classic business incubators may also have good relations with sources of funding, but they themselves are rarely business investors. Technology incubators support technology-oriented companies, mostly as new companies. According to Laskar \& Waheed (2016), business incubators are mapped into Corporate Private Incubators (CPIs), Business Innovation Centers (BICs), Independent Private Incubators (IPIs) and University Business Incubators (UBIs). Whereas in this study the business incubators studied were included in the University Business Incubators (UBIs) group. 
International Journal of Small Business and Entrepreneurship Research

Vol.8, No.2, pp.17-31, April 2020

Published by ECRTD-UK

Print ISSN: 2053-5821(Print), Online ISSN: 2053-583X (Online)

Incubation is an organization that supports startups to create innovation. Incubation is designed to support and help startups grow quickly from the initial period through various services such as shared workspaces, coaching and mentoring, training, creating collaboration networks and business advice (Dee et al., 2011). Incubation services and support are evaluated from the concept of sharing physical infrastructure such as workspace, equipment to current business support activities such as business consulting services, guidance, coaching, networking, business acceleration (Tehodorakopoulos et al. 2014). The new generation of incubation focuses on business skills and knowledge (Pauwel, et al. 2016).

Klaasa \& Thawesaengskulthai (2018) identified two incubation models; the first model, incubation emphasizes reducing initial costs for new startups by providing physical assets and commodity markets. The second model, incubation offers high-value services such as funding, business knowledge, operational support, and collaborative networks. Incubation services must be adjusted to the needs of the new startup.

Many researchers propose efficiency of incubation mechanisms. Chia (2013) classifies the benefits of incubation into four dimensions: developing credibility, shortening the learning curve, faster problem solving, and access to business networks. In addition, Barbero, et. al, (2012), suggested that the incubation process has to choose startup performance before entering the process since performance is the key to choosing the passion of a startup. Babwah \& David (2014) imply that a selection is one of the important tasks that incubators use to decide which will be accepted or rejected. In addition, there are two different selection approaches as follows: 1) Selection based on business ideas using the interviewer's knowledge and experience to evaluate possible ideas. 2) Selection based on startups by evaluating the personality, knowledge, experience, skills, and commitment of the startups (Klaasa \& Thawesaengskulthai, 2018).

The incubator process consists of three main stages: pre-incubation, incubation, and postincubation. The relation helps business incubators to adapt to various strategies to incubate new companies. Isabelle (2013) divides incubators into three categories with main services including initial capital providers, network amplifiers, business development services. Individual startups have the most influence on incubation models and services. Incubation must adjust the model accordingly to begin to improve the effectiveness and efficiency of management. Many research works have identified success factors for incubation around aspects of characteristics, activities, or events such as selection criteria that must take into account the capacity of the startup team, existing prototypes, and intellectual property, the guidance being business or technology experts who can provide useful advice for startups (Komi et al. 2015).

Most incubations are non-profit organizations. Entrepreneurs who work with business incubators are always local startup companies. Some incubators are managed by universities and do not invest in startup companies (Dempwolf et al., 2014). Business incubators managed by tertiary institutions have proven to be beneficial for entrepreneurs 
International Journal of Small Business and Entrepreneurship Research

Vol.8, No.2, pp.17-31, April 2020

Published by ECRTD-UK

Print ISSN: 2053-5821(Print), Online ISSN: 2053-583X (Online)

in a number of ways, such as by providing access to knowledge, facilities, and skilled labor (Lofsten and Lindelof, 2003; Dettwiler et al., 2006). Business incubators managed by universities can recruit students and alumni as educated human resources in a variety of different fields of science. Likewise, collaboration with teachers at these tertiary institutions can provide access to the latest knowledge in various domains and will offer opportunities to develop more innovative products (Felsenstein, 1994; Lockett and Wright, 2005; Nouira et al., 2005; Mian, 2011). University business incubators provide services provided to new entrepreneurs or MSMEs in two categories. The first category concerns general services offered by all incubators, such as offices, entrepreneurial assistance and access to finance. The second category refers to services related to college activities including academic coaches, access to graduates and students, use of research results or programs for technology transfer and training (McAdam \& Marlow, 2008).

Some previous research results show a variety of results related to how a business incubator should be managed in order to develop new businesses and MSMEs. The business incubator framework developed by Campbell et al., (1985) describes several stages in the business incubator, that new business incubators carry out several stages, namely carrying out a needs identification, conducting selection and mentoring, capital investment and access to expert networks. The business needs identification is assisted (tenant) in order to be able to compile a business proposal, which is then carried out incubation on the tent through a selection and mentoring program, capital investment and access to the network, after incubating the tenant it is expected that the tenant is able to have business capital so that the business is run will develop. The business incubator stage has also been developed by Smilor (1987), dividing the affiliation incubator into several types namely Private, University, Government and Non-Profit. The affiliated incubator will do the incubation for entrepreneurs (tenants) which includes Economic Development, Technology Diversification, Job Creation, Profits, Viable Companies, Successful Products. The business incubator itself must have a support system that is the secretariat of management, administration, facilities, business expertise. Verman (2004) developed a model of success factors for incubators. The model represents a theoretical framework for the success factor of the incubator. The main interest variable, the dependent variable, is the success rate of the incubator. The framework explains the differences in these dependent variables through a number of independent success factors categorized as 1) shared services, 2) facilities and locations 3) funding and support 4) incubator governance 5) incoming and outgoing tenant criteria and 6) mentoring and networking. Klasa and Thawesaengskulthai (2018) stated that there are ten key factors for an incubator to be successful, namely start-up team capacity, the idea of meeting the market demand, administrative support, training and coaching, Networking, Appropriate activities/programs, Business advice, Selected process, Mentorship, and Funds. Thus, ten critical success factors can be divided into factors of the incubation process based on 3 stages: pre-incubation, incubation, and acceleration (post-incubation). 
International Journal of Small Business and Entrepreneurship Research

Vol.8, No.2, pp.17-31, April 2020

Published by ECRTD-UK

Print ISSN: 2053-5821(Print), Online ISSN: 2053-583X (Online)

\section{RESEARCH METHODS}

The research method uses a literature review from the results of previous studies and from the results of obtaining information on business incubators managed by 69 universities in Indonesia. 69 university business incubators have been registered and registered in the database of the Ministry of Research, Technology and Higher Education (Kemenristekdikti) in 2019 and have been incorporated. In compiling an optimization model for the role of university business incubators to develop MSMEs, this research will be carried out in the following stages:

\section{Stage 1:}

Conducting a study of literacy associated with previous studies of the development of business incubators both an empirical study, theoretical review or case study, which is the main objective of the study was to identify 1) a key success factor for promoting MSMEs 2) the incubator and accelerator for promoting MSMEs and 3) obstacles to encourage MSMEs.

\section{Stage 2:}

Doing a collection of information and data related to business incubators in Indonesia managed by 69 universities. Information collected is related to the description of business incubators, general description of tenants / MSMEs coming in the incubation process, forms of cooperation offered by business incubators to MSMEs, the stages in the business incubation process.

\section{Stage 3:}

From the results of the FGD with other business incubator owners and data from open questionnaires from MSMEs, identification of development needs for MSMEs and alternative strategies that can be implemented by business incubators will be carried out.

\section{Stage 4:}

Develop an optimization model of business incubators role in the development of MSMEs by dividing them into 3 schemes, namely Pre-incubation, Incubation and Post Incubation.

\section{RESULT AND DISCUSSION}

The results of research through a literacy study of previous studies about the stages of managing business incubators and information processing of 69 business incubators managed by universities in Indonesia indicate that there are several stages that must be done so that a business incubator can optimize its role to develop new businesses and developing SMEs. The first thing to note is the business incubator itself, what the institution looks like, the infrastructure available in the incubator, the staff and expert team involved in all incubation processes to provide training or mentoring could given by teachers, students who have expertise and even graduates, market networking, funding networks, and business incubators generate the results of research or development of knowledge to 
International Journal of Small Business and Entrepreneurship Research

Vol.8, No.2, pp.17-31, April 2020

Published by $\boldsymbol{E C R T D}-\boldsymbol{U K}$

Print ISSN: 2053-5821(Print), Online ISSN: 2053-583X (Online)

support technology and innovation that can be used to develop businesses, and last but not least is the commitment and policy of the college to provide full support to implement the business incubators including university infrastructure facilities and funding for the management of business incubators, including support for experienced human resources in accordance with their fields of expertise. Next is to identify frequently problems occur and faced by new businesses and MSMEs that have started running their businesses and solutions that can be offered through business incubators can be seen in Table 1 below:

\section{Table 1. Problems and Solutions Offered by Business Incubators}

\begin{tabular}{|c|c|}
\hline The problem & The solution \\
\hline $\begin{array}{l}\text { Lack of financial capital, lack of } \\
\text { information about financial management, } \\
\text { sources of capital creation, weak expertise } \\
\text { and knowledge about managing finances }\end{array}$ & $\begin{array}{l}\text { Financial advisory, training on preparing } \\
\text { financial reports, helping to find sources of } \\
\text { funding and strategies to build trust to } \\
\text { obtain funding from third parties, } \\
\text { maximizing the resources they have by } \\
\text { preparing relevant revenue and } \\
\text { expenditure budgets in running their } \\
\text { business. }\end{array}$ \\
\hline $\begin{array}{l}\text { Lack of experience, knowledge, and } \\
\text { education about how to manage a business }\end{array}$ & $\begin{array}{l}\text { Training in business management from } \\
\text { various aspects of business, preparation of } \\
\text { business plans, evaluation of business } \\
\text { plans so that they are relevant, ongoing } \\
\text { assistance with the implemented business } \\
\text { plans }\end{array}$ \\
\hline $\begin{array}{l}\text { Weak information about the market, too } \\
\text { optimistic to see the market without } \\
\text { considering business risks, has not been } \\
\text { able to determine the target potential } \\
\text { customers }\end{array}$ & Market research, marketing advisor \\
\hline $\begin{array}{l}\text { Lack of consistency in maintaining product } \\
\text { quality and product standardization, a } \\
\text { weak understanding of product } \\
\text { differentiation and have not been able to } \\
\text { identify product advantages compared to } \\
\text { competitors }\end{array}$ & $\begin{array}{l}\text { Standard operational procedures, } \\
\text { especially for standardization of products, } \\
\text { packaging, and distribution }\end{array}$ \\
\hline Weak standards of service & $\begin{array}{l}\text { Excellent service training and strategy to } \\
\text { set service standards }\end{array}$ \\
\hline $\begin{array}{lll}\text { Lack of business relationships and } \\
\text { customer relationships }\end{array}$ & Networking \\
\hline $\begin{array}{l}\text { Weak in compiling business models, } \\
\text { business strategies and lack of information }\end{array}$ & $\begin{array}{l}\text { Business model advisory, management } \\
\text { Advisory }\end{array}$ \\
\hline
\end{tabular}


International Journal of Small Business and Entrepreneurship Research

Vol.8, No.2, pp.17-31, April 2020

Published by ECRTD-UK

Print ISSN: 2053-5821(Print), Online ISSN: 2053-583X (Online)

\begin{tabular}{|l|l|}
\hline $\begin{array}{l}\text { Weak knowledge of technology and } \\
\text { innovation }\end{array}$ & $\begin{array}{l}\text { Technology support from the results of } \\
\text { university research forms the center of } \\
\text { innovation studies }\end{array}$ \\
\hline $\begin{array}{l}\text { Lack of infrastructure to support the } \\
\text { business }\end{array}$ & $\begin{array}{l}\text { Providing infrastructure facilities by } \\
\text { collaborating with companies through } \\
\text { CSR programs or the government through } \\
\text { work programs for developing MSMEs to } \\
\text { be right on target }\end{array}$ \\
\hline
\end{tabular}

Source: processed for this study

Of the basic problems faced by new entrepreneurs and SMEs above, in this study compiled models that include several stages in order to optimize the role of university business incubator by dividing the incubation stage into three stages/phases are as follows :

1. Pre Incubation

2. Incubation Process

3. Post Incubation

Pre Incubation is the process of selecting prospective tenants who are new entrepreneurs or MSMEs that have been running and the process to determine ideas for preparing business plans, in the pre-incubation phase, the following steps need to be carried out:

1. Tenant Selection. The selection of effective tenants is an important part of the business incubation process because it increases the chances of a successful business incubation. Business incubators must be carefull to ensure the resources distribution is the most feasible new ventures. The importance of tenant selection for business incubators lies in the identification of new businesses with the potential to grow and succeed. The process of selecting tenants with criteria includes: (1) being a local tenant, (2) being a new entrepreneur or MSME having the problems listed in table 1 , although is not limited to the problems mentioned above, (3) tenants are committed to follow the entire incubation process, (4) tenants are willing to follow all existing provisions in accordance with what is required by the business incubator, (5) tenants are grouped based on the problems faced because it will be adjusted to the incubation program that will be done, (6) business ideas or Tenant business that has been carried out is a business that is relevant to be run and feasible to be developed.

2. Submission and selection of business ideas. At this stage, tenants develop individual ideas by gathering ideas, selecting the best ideas, developing prototypes, and the market testing. During the process, the business incubator must examine the innovation ideas made by the expert committee in accordance with the related fields to make the business idea clearer. Further support will provide innovative ideas. Incubation must provide space and business consultants to help start to create better business ideas, provide training on how to create business models to be able to implement business ideas. The business idea chosen must be adapted to the needs of consumers and be accepted by the market. 
International Journal of Small Business and Entrepreneurship Research

Vol.8, No.2, pp.17-31, April 2020

Published by ECRTD-UK

Print ISSN: 2053-5821(Print), Online ISSN: 2053-583X (Online)

3. The output of this phase is a business proposal that contains a valid and reliable business idea so that it can be used as a basis for continuing the next phase.

The incubation process is a phase where the incubator provides support to tenants to implement business ideas that have been prepared in the pre-incubation phase from the beginning of the expansion phase, usually a physical incubation, assistance, training, network acquisition. In the incubation phase, the following steps need to be carried out:

1. Training and Coaching. The tenant on this phase will be given training on various aspects of both aspects of marketing, production aspects, financial aspects, and human resources as well as technology and innovation, the tenant will also be trained related soft skills needed for tenant has the ability and reliability to entrepreneurship. The training also related to the concept of excellent service for consumers and other stakeholders. This training and coaching is conducted according to the needs of tenants.

2. Networking. Tenant will be given the opportunity to find and open a network with existing networks given by colleges or a new network tailored to the needs of business tenants. The intended network can be a network for suppliers, a network to the market, a network to consumers to find potential customers, a distribution channel network and even a network for the government.

3. Find suitable financial sources. Tenants will be assisted in relation to finding financial resources for their business, both from personal capital by maximizing existing resources, capital from third parties including banks and other investors. Funding can also come from government and corporate programs through CSR to participate in developing local MSMEs.

4. Market research. The team accompanied by the incubator team will conduct a market analysis to be able to develop the market strategies. Market research is carried out to identify whether the product produced can be accepted by the market, how to describe competitors so that they have a strategy to deal with it, find out the segmentation, positioning, and business target market.

5. Making a business permit. Tenant learns about the concept of a business permit, the stages of filing up to registering a business license.

6. Standard Operasional Procedurs on product standardization, packaging, distribution, and service. Develop operational standard procedures on product standardization, namely the process of purchasing raw materials, recording inventory, production processes, packaging of finished goods distributions, processing industrial waste, as well as service procedures.

7. Technology and Innovation. To support the business of the tenant, technology and innovation are needed that are tailored to the business type of tenant. For example, technology related to digital marketing, production processes, product differentiation and marketing innovation.

8. Technical guidance, in this incubation phase, tenants get the technical guidance related to all business processes in accordance with the business fields, the training and skills development that has been followed, how should the business be run from the planning, organizing, business implementation, and business evaluation 
Vol.8, No.2, pp.17-31, April 2020

Published by $\boldsymbol{E C R T D}-\boldsymbol{U K}$

Print ISSN: 2053-5821(Print), Online ISSN: 2053-583X (Online)

processes. This technical guidance is mentored by experts according to their expert fields, and carried out consistently, periodically and do a periodically evaluation.

9. Trial of Business Implementation. Tenant applies all the knowledge and expertise gained in the incubation process to leap directly into the market in an effort to test the success of the incubation phase.

10. The output of the incubation phase is that tenants are able to develop business concepts that are complete, tested and bankable, and are able to implement their business.

Post Incubation is a phase related to the activities that will be carried out when the company has reached a feasible phase to run its business independently and is profit-oriented. In the post-incubation phase the following steps need to be carried out:

1. Business feasibility test. Before leaving the incubation program, a feasibility test will be conducted until the tenant business can stand independently and can generate a decent profit so that the tenant business can develop and grow sustainably.

2. Tenant left the Incubation Program. If the tenant has been declared eligible then the tenant has completed the incubation program and come out the incubation program to carry out his business in a real way.

3. Evaluation, Monitoring, and Sustainability of the Incubation Program. Even though the tenant has completed the incubation program and has left the incubation program, the business incubator is obliged to carry out an evaluation and monitoring of the tenant's business within a certain period, and if further steps are needed for the more expert then the tenant can follow the incubation process again but with the higher level incubation.

4. The output of the post-incubation phase is that tenants are able to implement their business with profit-oriented and business development.

From all the above stages of the incubation phase carried out by the university business incubator, it can be described as a model of optimizing the role of the business incubator as follows: 


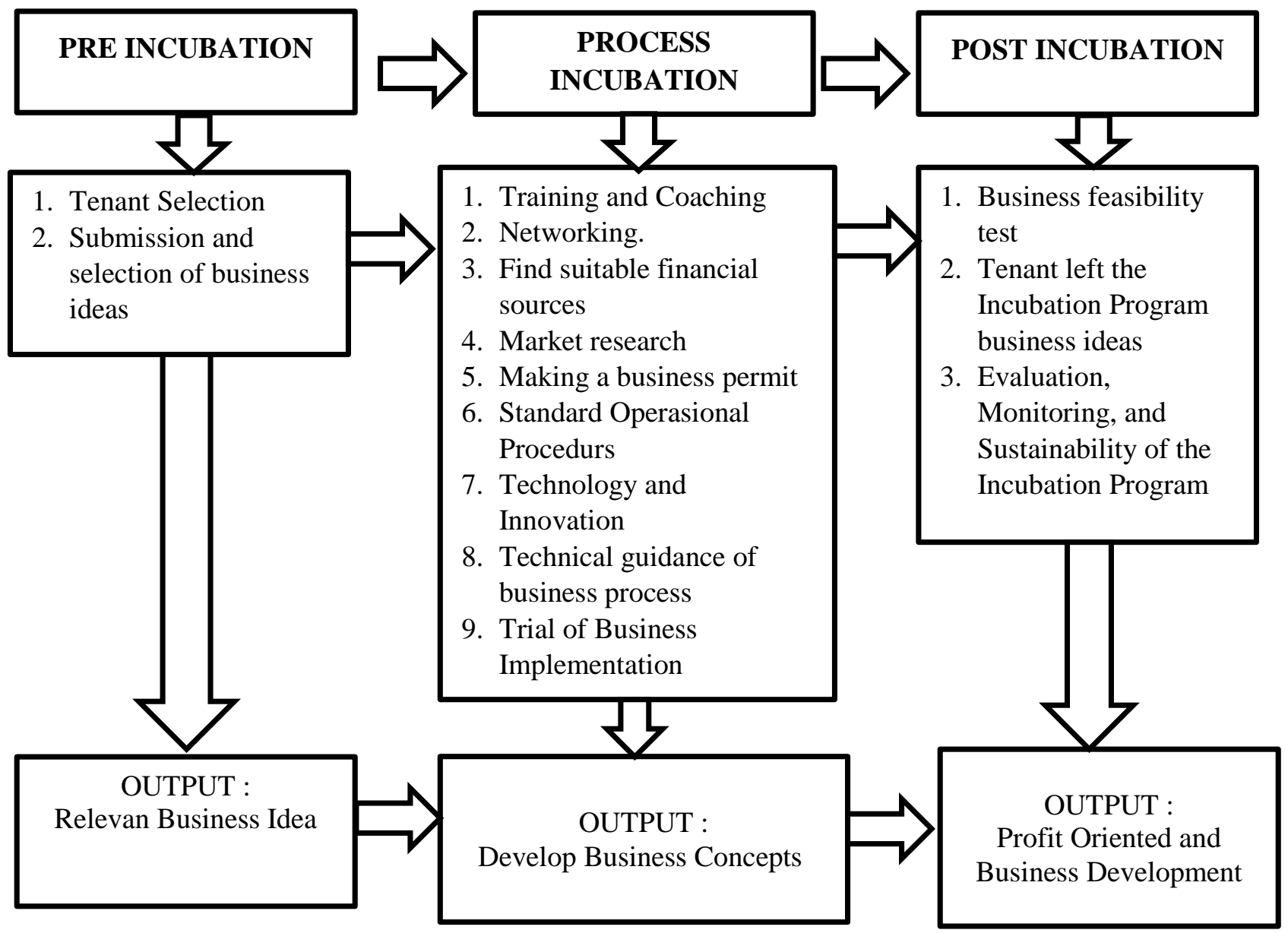

Figure 1. Optimization Role Model of University Business Incubators

The picture above shows the stage/phase model that must be carried out by business incubator managed by a university could be successful and sustainable. If all the steps are carried out correctly, new entrepreneurs and MSMEs with competitive competitiveness will be created. The key to implementing business incubation lies in the commitment of the business incubator management and the commitment of the tenants to be incubated to be able to follow the entire set of incubation stages consistently and meet the applicable standards.

\section{CONCLUSION AND FUTURE RESEARCH}

Business incubators have an important role in encouraging the development of new businesses and MSMEs to survive and grow in a competitive business environment. This study discusses the optimal model of the role of the business incubator managed by universities in Indonesia. This study develops a framework of incubation models based on theoretical and literation based on optimizing the role 
International Journal of Small Business and Entrepreneurship Research

Vol.8, No.2, pp.17-31, April 2020

Published by ECRTD-UK

Print ISSN: 2053-5821(Print), Online ISSN: 2053-583X (Online)

of incubation models. The incubation optimization model consists of pre-incubation, incubation, and post-incubation. Each stage/phase is an activity that has the main objective to develop the knowledge and expertise of tenants related to business management. The pre-incubation phase focused on the selection of tenants and developing a business idea in accordance with market needs. The incubation phase focuses on making the concept of the business to be implemented into the market through mentoring and training, basic skills and advanced to be able to manage the business competitive. The post incubation phase focuses on increasing the potential of startups to new markets, the readiness of tenants to stand independently and the stages of evaluation and monitoring to assess the success and sustainability of the incubation program that has been carried out. This research also focuses on the commitment of universities as managers of business incubators to consistently provide infrastructure and human resources so that this incubation program can run optimally.

The success of incubation begins with tenants who have passion and commitment. Under the incubation process, there are a number of factors that support successful incubation including administrative support, training and mentoring, business advice, mentors, and networking. Business incubators must act as knowledge centers that encourage the business community to exchange ideas between inside and outside incubation. Incubation must create a system of value-added networks between government, universities, the private sector, and the community. The value-added network system provides stakeholders with realtime capabilities of two-way transactions. Future studies are expected to test the feasibility of an optimalization model of the business incubators role through the evaluation results of program success by identifying tenant's conditions that have emerged from incubation since they have passed the post-incubation phase. This evaluation is carried out to measure whether the model is effectively able to develop new entrepreneurs or MSMEs as the tenants of the business incubator.

\section{REFERENCES}

Aggarwall, R., Siddiqaliali, B., M. and Kumar, P. (2012) Technology and Business Incubation a Proven model to promote technology innovation and entrepreneurship in Rwanda. International Journal of Business and Public Management. Vol.2. Pg.4750 .

Al-Mubarak, H.N. \&Musler, R. (2013) The Effect of Business Incubation in Developing Countries. European Journal of Business and Innovation Research, Vol. 1, No. 1, March 2013, 19-25.

Babwah, N. R. and David, J. M. (2014) Selecting the Right Clients for a Business Incubator-Lessons Learnt from the National Integrated Business Incubator System (IBIS) Programme in Trinidad and Tobago. Journal of Small Business and Entrepreneurship Development. Vol. 2, No. 3 \& 4, pp. 13-26.

Barbero, J.L. , Casillas, J.C. , Ramos, A. and Guitar, S. (2012) Revisiting Incubation Performance: How Incubator Typology Affects Results. Technological Forecasting and Social Change, Vol. 79 No. 5, pp. 888-902. 
International Journal of Small Business and Entrepreneurship Research

Vol.8, No.2, pp.17-31, April 2020

Published by ECRTD-UK

Print ISSN: 2053-5821(Print), Online ISSN: 2053-583X (Online)

Beats, W. (2013) Complexity, Uncertainty and Societal Responsibility: The paradigm of the emergent economy. While we cannot teach entrepreneurship, we can do so many interesting things. Graduate School of Business. University of Cape Town.

Campbell, C., Kendrick, R. C., and Samuelson, D. S. (1985) Stalking The Latent Entrepreneur: Business Incubators and Economic Development. Economic Development Review. Vol. 3. No. 2. Pg. 43-49.

Cantu, C. (2015) A Service Incubator Business Model: External Networking Orientation. IMP Journal. Vol. 9 No. 3, pp. 267-285.

Chia, H. (2013) Technology Timing of IPOs and Venture Capital Incubation. Journal of Corporate Finance 19. Pg.36-55.

Dee N. J., Livesey F., Gill D. and Minshall T. (2011) Incubation for Growth : A review of The Impact of Business Incubation on New Ventures with High Growth, Nesta Report.

Dempwolf, C. S., Auer, J. and D'Ippolito, M. (2014) Innovation Accelerators: Defining Characteristics Among Startup Assistance Organizations. US Small Business Administration.

Dettwiler, P., Lindelof, P. and Lofsten, H. (2006) Utility of Location: A Comparative Survey Between Small New Technology-Based Frms Located On and Off Science Parks - Implications For Facilities Management. Technovation, Vol. 26 No. 4, pp. 506-517.

Dey, P. (2012) Incubation of Micro and Small Enterprises- An Approach to Local EconomicDevelopment. International Journal of Scientific and Engineering Research. Vol.3. Issue.5.

Felsenstein, D. (1994) University-Related Science Parks-'Seedbeds' or 'Enclaves' of Innovation?. Technovation, Vol. 14 No. 2, pp. 93-110.

Isabelle, D.A. (2013) Key Factors Affecting a Technology Entrepreneur's Choice of Incubator or Accelerator. Technology Innovation Management Review. February 2013: 16-22.

Klaasa, P., and Thawesaengskulthai, N. (2018) Incubation Framework for A New Startup: A Case Study in Thailand. Proceedings of the International Conference on Industrial Engineering and Operations Management. Bandung, Indonesia, March 6-8.

Komi, M., Stil, K., Wallin, A. and Jaring, P. (2015) Accelerating the Innovation Process of Start-Ups-Business Incubator and Accelerator Services in Finland. The XXVI ISPIM Conference-Shaping the Frontiers of Innovation Management, Budapest, Hungary on 14-17 June.

Laskar, S. K. and Waheed, K. (2016) Substantive Incubation For Growth and Its ICT Impact On MSME's. International Journal of Business and Management, Vol. IV, No. 4.

Lesakova, L. (2012) The Role of Business Incubators in Supporting the SME Start-up. Acta Polytechnica Hungarica, Vol. 9, No. 3, pp. 85-95.

Lockett, A. and Wright, M. (2005) Resources, Capabilities, Risk Capital and The Creation of University Spin-Out Companies. Research Policy, Vol. 34, pp. 1043-57.

Lofsten, H. and Lindelof, P. (2003) Determinants for An Entrepreneurial Milieu: Science Parks and Business Policy in Growing Firms. Technovation, Vol. 23, pp. 51-64. 
International Journal of Small Business and Entrepreneurship Research

Vol.8, No.2, pp.17-31, April 2020

Published by $\boldsymbol{E C R T D}-\boldsymbol{U K}$

Print ISSN: 2053-5821(Print), Online ISSN: 2053-583X (Online)

McAdam, M., and Marlow, S. (2008) A Preliminary Investigation Into Networking Activities Within The University Incubator. International Journal of Entrepreneurial Behaviour \& Research, 14(4), 219-241.

Meru, A.K. and Struwig, B. (2011) An Evaluation of The Entrepreneur's Perception of Business Incubation in Kenya. International Journal of Business Administration, 2 (4), pp. 112-121.

Mian, S. A. (2011) University's Involvement in Technology Business Incubation: What Theory and Practice Tell Us? International Journal of Entrepreneurship and Innovation Management, 13(2), 113-121.

Monsson, C. K. and Jorgensen, S. B. (2016) How do Entrepreneurs' Characteristics Influence The Benefits from The Various Elements of a Business Incubator?. Journal of Small Business and Enterprise Development. Vol. 23 No. 1, pp. 224-239.

Nouira, S., Klofsten, M. and Dahlstrand, A. (2005) The Logic of The Entrepreneur: Implications of The Entrepreneur's Perception of Early-Stage Financing. International Journal of Entrepreneurship and Innovation, Vol. 6 No. 2, pp. 85-96.

Pauwels, C., Clarysse, B., Wright, M. and Van Hove, J. (2016) Understanding a New Generation Incubation Model: The Accelerator. Technovation, 50-51, 13-24.

Petrucci, F. (2018) The Incubation Process of Mid-Stage Startup Companies: A Business Network Perspective. IMP Journal. Vol. 12 No. 3, pp. 544-566.

Redondo, M. and Camarero, C. (2017) Dominant Logics and The Manager's Role in University Business Incubators. Journal of Business \& Industrial Marketing 32/2, 282-294

Shepard, J. M. (2013) Small Business Incubators in The USA: A Historical Review and Preliminary Research Findings. Journal of Knowledge-based Innovation in China Vol. 5 No. 3, pp. 213-233

Smilor, R.W. (1987) Managing the Incubator System: Critical Success Factors to Accelerate New Company Development. IEEE Transaction on Engineering Management EM-34 (4), 146-156.

Stokes, D. and N. Wilson. (2010). Small Business Management and Entrepreneur. 6th ed, Andover, Cengage.

Theodorakopoulos, N., Kakabadse, N.K. and McGowan, C. (2014) What Matters in Business Incubation? A Literature Review and a Suggestion for Situated Theorising. Journal of Small Business and Enterprise Development, Vol. 21 No. 4, pp. 602-622.

Verman, S. (2004) Success Factors for Business Incubators: an Empirical Study of Canadian Business Incubators. Eric Sprott School of Business, Carleton University, Ottawa, Ontario.

$\mathrm{Xu}, \mathrm{L}$. (2010) Business Incubation in China Effectiveness and Perceived Contributions to Tenant Enterprises. Management Research Review. Vol. 33 No. 1, pp. 90-99. 